(C) 2020, The Authors. Published by Elsevier Inc. and Fass Inc. on behalf of the American Dairy Science Association ${ }^{\circledR}$. This is an open access article under the CC BY-NC-ND license (http://creativecommons.org/licenses/by-nc-nd/4.0/).

\title{
Effect of bismuth subnitrate on in vitro growth of major mastitis pathogens
}

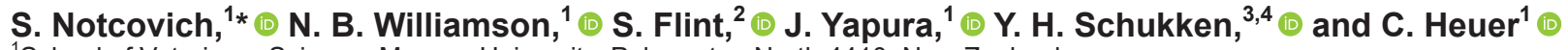 \\ ${ }^{1}$ School of Veterinary Science, Massey University, Palmerston North 4410, New Zealand \\ ${ }^{2}$ Massey Institute of Food Science and Technology, Massey University, Palmerston North 4410, New Zealand \\ ${ }^{3}$ Department of Animal Sciences, Wageningen University, Wageningen, the Netherlands, $6700 \mathrm{AH}$ \\ ${ }^{4} \mathrm{GD}$ Animal Health, Deventer, the Netherlands, 7400 AA
}

\begin{abstract}
The mode of action of bismuth subnitrate in teat sealant formulations as a preventative for intramammary infections during the dry period is unknown. Although previous studies proposed an action mechanism - creating a physical barrier in the teat canal to prevent bacterial invasion - it has not been proven experimentally. We hypothesized that bismuth subnitrate has an inhibitory effect on bacterial growth, in addition to its barrier effect. The objective of this study was to assess the effect of bismuth subnitrate on bacterial growth of major mastitis-causing agents. A strain of Streptococcus uberis (SR115), 2 strains of Staphylococcus aureus (SA3971/59 and SA1), and a strain of Escherichia coli (P17.14291) were tested in vitro for their ability to grow in the presence or absence of bismuth subnitrate. Disk diffusion testing, impedance measurement, and evaluation of bacterial growth in shaking conditions were the methods used to test this hypothesis. A reduction of growth in the presence of bismuth subnitrate occurred for all the strains tested. However, we observed strain and species variations in the extent of growth inhibition. These results suggest that an inhibitory effect on bacterial growth by bismuth subnitrate could partially explain the efficacy of bismuth-based formulations for preventing intramammary infections over the dry period. Further research is required to test the effect of teat sealant formulations on bacterial growth.
\end{abstract}

Key words: bismuth subnitrate, mastitis, teat sealant, dry cow

\section{INTRODUCTION}

The late lactating and early dry periods are stressful stages for the anatomy and physiology of dairy cows, particularly their mammary glands. Remodeling,

Received October 31, 2019.

Accepted March 22, 2020.

*Corresponding author: s.notcovich@massey.ac.nz apoptosis, and cell dedifferentiation are processes occurring in mammary glands during the first 2 wk after milk removal ceases (Cousins et al., 1980; Wilde et al., 1997). This time-specific physiological stress is manifested by high susceptibility of cows to new IMI (Green et al., 2002). Thus, methods to treat and prevent IMI during the dry period have been available for many years. These treatments consist mainly of antimicrobials infused into mammary glands after the last milking before drying off, and they result in a reduction of new IMI during the dry period in treated compared with untreated cows (Pearson and Wright, 1969; Schukken et al., 1993; Bryan et al., 2011). Dry cow therapy (DCT) has been used on all cows in a herd, regardless of their infection status, with the objective of eliminating subclinical infections and preventing new infections during the dry period (Williamson et al., 1995; Hassan et al., 1999). However, due to global concerns regarding increasing antimicrobial resistance and the need for responsible use of antimicrobials, there is a trend toward investigating the use of selective dry cow therapy and nonantimicrobial alternatives (Oldham and Daley, 1991; Ryan et al., 1998; Hoernig et al., 2016; Vanhoudt et al., 2018). The current and most commonly used alternatives to antimicrobials at the time of dry-off are internal teat sealants that contain bismuth subnitrate, a heavy metal compound, in a paraffin-based excipient. They have proven to be effective at preventing new dry-period infections in challenge models, as well as in natural exposure studies (Meaney, 1977; Woolford et al., 1998; Bhutto et al., 2011). The mechanism of action of bismuth-based products remains undocumented, although creating a physical barrier has been suggested in many studies as the main method of protection (Meaney, 1977; Woolford, et al., 1998; Berry and Hillerton 2002; Kabera et al., 2018). Internal teat sealants are also commonly used in combination with DCT, to prevent and treat IMI during the dry period (Godden et al., 2003). However, although there is an increase in the efficacy of preventing IMI using both products in combination, this increase is nonsignificant (Rabiee and Lean, 2013). 
Bismuth formulations used as internal teat sealants are defined as "medical devices," a nonpharmacological barrier (Codex Alimentarius, 2016). The proposed mechanisms through which teat sealants exert their function include assisting the teat canal in forming a better keratin plug and creating a physical barrier against bacteria in the teat canal (Woolford et al., 1998); however, none of these hypothesized modes of action has been scientifically proven. Other studies testing different physical barriers, such as wax plugs or intramammary polystyrene devices, were unsuccessful in the long-term protection of cows against IMI and mastitis. Even though intramammary devices elicited some immune response and a seemingly initial protective effect (Poutrel et al., 1983; Paape et al., 1988; Nickerson et al., 1990; Serna-Cock and Pabón-Rodríguez, 2016), in the long term these devices resulted in an increase in IMI. We hypothesize, therefore, that creating a physical barrier against bacteria traversing the teat canal is not the sole mode of action providing the efficacy observed for bismuth-based formulations.

Studies have shown an inhibitory effect of bismuthbased products when tested in vitro against bacterial species that are associated with disease in humans (Phillips et al., 2000; Folsom et al., 2011; Vega-Jiménez et al., 2012). Inhibition of bacterial growth by bismuth salts (mainly bismuth subsalicylate) has been studied in the treatment of stomach ulcers, traveler's diarrheas, and colitis caused by bacteria such as Helicobacter pylori and Campylobacter pyloridis (Marshall et al., 1987; Fine and Lee, 1998).

In this study, we hypothesized that bismuth subnitrate inhibits the growth of bacteria associated with the colonization of the mammary gland during the dry period and the development of new IMI. The objective of this study was to assess the effect of bismuth subnitrate on the growth of mastitis-causing bacterial strains in vitro.

\section{MATERIALS AND METHODS}

\section{Bacterial Strains}

Streptococcus uberis strain SR115, 2 strains of Staphylococcus aureus (SA3971/59 and SA1), and an Escherichia coli strain (P17.14291) were used in this study. The source of the Staph. aureus and Strep. uberis strains was the bacteria library in the Microbiology Laboratory, School of Veterinary Science, Massey University, New Zealand, and they were originally isolated by veterinary diagnostic laboratories from clinical mastitis cases that occurred in New Zealand from various stages of lactation. Escherichia coli was isolated from an early lactation clinical case of mastitis that occurred in August 2017 at Massey University Dairy Unit number 4. For complete identification, the Strep. uberis and Staph. aureus isolates were cultured on trypticase soy agar plates (TSA) and incubated in aerobic conditions at $37^{\circ} \mathrm{C}$ for $24 \mathrm{~h}$. To confirm strain purity, one colony from each strain was selected from the culture plate, transferred onto a new TSA plate, and incubated as above. The isolates were reidentified phenotypically using biochemical tests. Streptococcus uberis SR115 was confirmed by positive Gram stain, catalase-negative, esculin and inulin positive reactions, and negative growth in buffered azide glucose glycerol broth. Positive results for Gram stain, catalase reaction, and coagulase rabbit plasma test confirmed isolates as being Staph. aureus SA3971/59 and SA1. Escherichia coli P17.14291 was cultured on MacConkey agar.

\section{Experiment 1: Bacterial Growth in Agar-Disk Diffusion Test}

To test the hypothesis that bismuth subnitrate can inhibit the growth of bacteria on agar media, bacterial strains were cultured overnight at $37^{\circ} \mathrm{C}$ in $1 \mathrm{~mL}$ of trypticase soy broth (TSB). One hundred microliters of each bacterial suspension was spread on TSA plates. These bacterial strain suspensions were cultured overnight to contain approximately $10^{8}$ to $10^{9} \mathrm{cfu} / \mathrm{mL}$. Sterile bismuth subnitrate powder was suspended in sterile distilled water at 3 different concentrations (65, 195 , and $390 \mathrm{mg} / \mathrm{mL}$ ) and vortexed thoroughly to create a uniform suspension. Concentrations were chosen to represent 10, 30, and $60 \%$ of the $650 \mathrm{mg} / \mathrm{g}$ present in current teat sealant products (drySeal, Bayer Animal Health, New Zealand). Higher concentrations induced precipitation of the bismuth subnitrate in the tubes and were therefore not used. Sterile $6-\mathrm{mm}$ paper disks were immersed in the bismuth subnitrate suspensions and placed on the plates, and the plates were incubated for $24 \mathrm{~h}$ at $37^{\circ} \mathrm{C}$. One extra disk was immersed in sterile distilled water and used as a control. After incubation, the plates were observed for zones of inhibition and changes around the disks at the different concentrations and the diameters of the zones were measured with a $20-\mathrm{cm}$ caliper. The experiment was performed in 5 plates for each strain.

\section{Experiment 2: Bacterial Growth in a Fluid Medium- Impedance Standardization}

The hypothesis of this experiment was that bismuth subnitrate inhibits the growth of bacteria in a fluid medium. During the growth phase, bacterial metabolism breaks down proteins and lipids in the medium and transforms uncharged or weakly charged compounds 
of the culture medium into highly charged compounds that change the electrical properties of the medium. Impedance in microbiology is the ability of a microorganism to change (reduce) the resistance to flow of an electric current as it passes through a conducting material (Silley and Forsythe, 1996). Impedance was measured using the BacTrac 4300 microorganism growth analyzer (SyLab, Neupurkersdorf, Austria). The BacTrac 4300 measures impedance in the medium ( $M$-value) and impedance in the electrode ( $E$-value). In this experiment, the $E$-value generated by BacTrac was used, as it has been shown to be positively associated with bacterial growth (Wang et al., 2016). Bacterial strains were cultured overnight in $1 \mathrm{~mL}$ of TSB at $37^{\circ} \mathrm{C}$. Bismuth subnitrate in a final concentration of $32.5 \mathrm{mg} /$ $\mathrm{mL}$ (BIS, $5 \%$ of the $650 \mathrm{mg} / \mathrm{g}$ contained in teat sealant product) was added to sterile BacTrac vials containing $9.9 \mathrm{~mL}$ of TSB, which were vortexed. Control vials containing $9.9 \mathrm{~mL}$ of sterile TSB $(\mathbf{C O N})$ were filled with $0.325 \mathrm{~mL}$ of sterile distilled water (to correct for volume) and vortexed to mix. One hundred microliters of bacterial strain suspension cultured overnight, containing approximately $10^{8}$ to $10^{9} \mathrm{cfu} / \mathrm{mL}$, was added to all vials. The vials were cultured for $24 \mathrm{~h}$ at $37^{\circ} \mathrm{C}$ in the BacTrac. The $E$-value was monitored every $20 \mathrm{~min}$ for $24 \mathrm{~h}$, and a curve expressing the increase in impedance over time was drawn, compared with the starting point at time 0 . The experiment was performed in triplicate, in 4 repeats per strain (12 vials per treatment).

Before and after culture in the BacTrac, viable bacteria were counted for validation of the results using the pour plate technique. Briefly, a $100-\mu \mathrm{L}$ sample from the BacTrac vials (6 per strain) was transferred into 1.5-mL sterile tubes containing $900 \mu \mathrm{L}$ of TSB. These suspensions were serially diluted $10^{-3}$ to $10^{-7}$ and transferred into sterile empty petri dishes. Trypticase soy agar was poured over the plates containing the bacterial suspension, and the plates were incubated at $37^{\circ} \mathrm{C}$ for $24 \mathrm{~h}$. Viable colonies were counted after incubation of the plates.

\section{Experiment 3: Bacterial Growth in a Shaking Fluid Medium}

The hypothesis of this experiment was that by shaking the medium, bismuth subnitrate particles would come in closer contact with bacterial cells and therefore increase the inhibition of bacterial growth.

Bacterial strains were cultured overnight in $1 \mathrm{~mL}$ of TSB at $37^{\circ} \mathrm{C}$. Glass Erlenmeyer flasks were filled with $9.9 \mathrm{~mL}$ of sterile TSB in triplicate. Bismuth subnitrate was added at a final concentration of $32.5 \mathrm{mg} / \mathrm{mL}$ (BIS). Control flasks without bismuth $(\mathrm{CON})$ received $0.325 \mathrm{~mL}$ of sterile distilled water to correct for volume.
One hundred microliters of the overnight bacterial culture (approximately $10^{8}$ to $10^{9} \mathrm{cfu} / \mathrm{mL}$ ) was added to all the flasks. Two trials were run with this method to observe the effect of longer incubation time on bacterial growth. In trial 1 , the flasks were placed on a shaking platform at $200 \mathrm{rpm}$ for $24 \mathrm{~h}$ for culturing. In trial 2 , the flasks were cultured in shaking mode for $48 \mathrm{~h}$. Aliquots of $100 \mu \mathrm{L}$ of the culture medium were taken at multiple time points to count the number of viable colonies: immediately after inoculation $(0 \mathrm{~h})$, at 3,5 , and $24 \mathrm{~h}$ for trial 1 , and at $0,3,5,24$, and $48 \mathrm{~h}$ after inoculation for trial 2 . The $100-\mu \mathrm{L}$ aliquots were serially diluted 10-fold in $0.9 \mathrm{~mL}$ of TSB. These serial dilutions were processed for counting (cfu) using the pour-plate technique described above.

\section{Statistical Analysis}

For experiment 1, the outcome "diameter of dark area around the disk" had an approximately normal distribution. A standard ANOVA with post hoc Tukey-Kramer adjustment for multiple paired comparisons was used to compare the diameter (in millimeters) associated with each strain at different concentrations. For experiment 2, results are presented as LSM estimates of the $E$-value $\pm 95 \% \mathrm{CI} \times$ time. Statistical differences were based on Tukey-Kramer adjusted pairwise comparison per strain. The repeated measure model included the fixed effects of treatment (BIS vs. CON), time ( 0 to $24 \mathrm{~h}$ in 20 min intervals) and the interaction between treatment and time. Vials with incomplete curves due to a malfunction of the electrodes were dropped from the analysis. Seven vials of Strep. uberis SR115, 9 of Staph. aureus SA3971/59, 6 of Staph. aureus SA1, and 8 of E. coli P17.14291 were removed from the analysis for this reason. Viable counts (cfu) were not normally distributed and were therefore converted to $\log _{2}$-cfu values. Paired Student's t-test was used to compare the difference of $\log _{2}$-cfu before $(0 \mathrm{~h})$ and after culturing $(24 \mathrm{~h})$ for BIS and CON groups. Student's $t$-test was used to compare the mean difference of the $\log _{2}$-cfu between groups (BIS vs. CON) at each time point. For experiment 3 , the count data were right-skewed but an e-log conversion of the colony-forming units/10,000 counts showed an approximately normal distribution, as evaluated using density plots. The outcome was the mean of triplicate plate counts per treatment (BIS, CON) per strain showing between 30 and $300 \mathrm{cfu}$. Four repeated-measures models, one for each strain (PROC MIXED, SAS 9.3 for Windows; SAS Institute Inc., Cary, $\mathrm{NC}$ ), were developed to determine the effect of bismuth supplementation on bacterial growth at each time point $(0,3,5,24$, and $48 \mathrm{~h})$ in shaking culture for both trials. The model included the fixed effect of time $(0,3$, 
$5,24,48 \mathrm{~h}$ ), trial (1 vs. 2), treatment (BIS vs. CON) and interaction of time and treatment. To account for the correlation of repeated measures within group, the model for a cluster effect of group was nested within the experiment $(1,2)$ and a first-order autoregressive correlation structure, assuming that measurements closer in time were correlated more strongly. This structure resulted in the lowest Akaike information criterion as a measure of overall model fit. The significance level for all statistical tests was set at $P<0.05$. All statistical analysis was done in SAS 9.3.

\section{RESULTS}

\section{Experiment 1: Bacterial Growth in Agar-Disk Diffusion Test}

An area 7- to 10-mm in diameter of complete inhibition, which coincided with the spread of the suspended bismuth subnitrate when wet disks were placed on the agar, was present around disks in the Strep. uberis SR115 cultures in 3 different concentrations (Figure 1A). Control disks showed no inhibition for any of the strains tested.

The 2 Staph. aureus strains (SA3971/59 and SA1) and E. coli P17.14291 on agar plates presented an area of partial inhibition (less-dense colony growth around the disks; Figure 1B), and a dark brown area around the disks that was larger for higher concentrations (Figure 2), although complete inhibition was not observed for these bacteria. Brown areas around the disks varied with concentration within each Staph. aureus strain [SA1 $(65 \mathrm{mg} / \mathrm{mL})$ vs. SA1 $(390 \mathrm{mg} / \mathrm{mL}), P=0.0048$; SA3971/59 $(65 \mathrm{mg} / \mathrm{mL})$ vs. SA3971/59 $(390 \mathrm{mg} / \mathrm{mL})$, $P=0.0186]$. However, paired comparisons showed no difference between strains.

\section{Experiment 2: Bacterial Growth in a Fluid Medium}

The impedance of the medium was measured using the BacTrac 4300 microbiological growth analyzer. Growth curves showed lower impedance levels for all strains cultured in TSB medium when supplemented with $32.5 \mathrm{mg} / \mathrm{mL}$ bismuth subnitrate, compared with the control growth curve (Figure 3). Vials that showed incomplete reads due to having out-of-range values during the 24-h culture were removed from the study. Of the 24 vials per strain analyzed, 7 vials of Strep. uberis SR115, 9 of Staph. aureus SA3971/59, 6 of Staph. aureus $\mathrm{SA} 1$, and 8 of E. coli $\mathrm{P} 17.14291$ were removed from the analysis. The results of the impedance test showed that inhibition of bacterial growth was not complete. Changes in impedance levels occurred, indicating bacterial growth. There was evidence of growth in the first $10 \mathrm{~h}$ of culture in the BIS treatment group, although lower than in CON vials for the duration of the study. Significant differences between BIS and CON vials were detected after $4 \mathrm{~h}$ in SA3971/59 and SA1, after $5 \mathrm{~h}$ in SR115, and after $10 \mathrm{~h}$ in E. coli P17.14291 (Figure 3). Counts (cfu) \pm SD were assessed before incubation $(0$ h) and $24 \mathrm{~h}$ after incubation for 6 selected vials per strain (Table 1). Plate counts indicated that there was reduced bacterial growth in the BIS group after $24 \mathrm{~h}$ of culture for the 4 bacterial strains tested compared with the CON group ( $t$-test, $P<0.001)$.

\section{Experiment 3: Bacterial Growth in a Shaken Fluid Medium}

Colony-forming units in BIS and CON groups were counted at 4 and 5 time points over 24 - and 48 -h periods for trials 1 and 2, respectively. Results showed significant growth inhibition by bismuth subnitrate

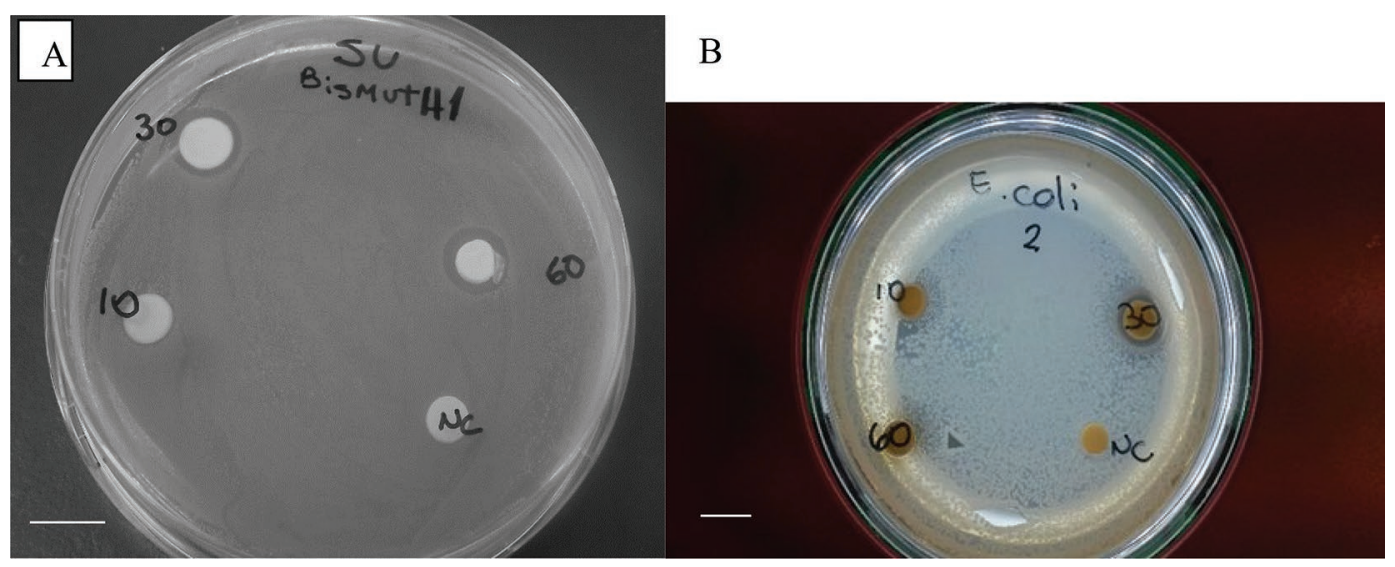

Figure 1. (A) Experiment 1: Complete inhibition of growth of 7 to $10 \mathrm{~mm}$ around the disks of a trypticase soy agar plate cultured with

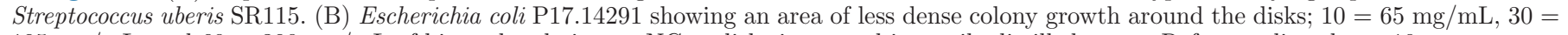
$195 \mathrm{mg} / \mathrm{mL}$, and $60=390 \mathrm{mg} / \mathrm{mL}$ of bismuth subnitrate, $\mathrm{NC}=$ disks immersed in sterile distilled water. Reference line shows $10 \mathrm{~mm}$. 


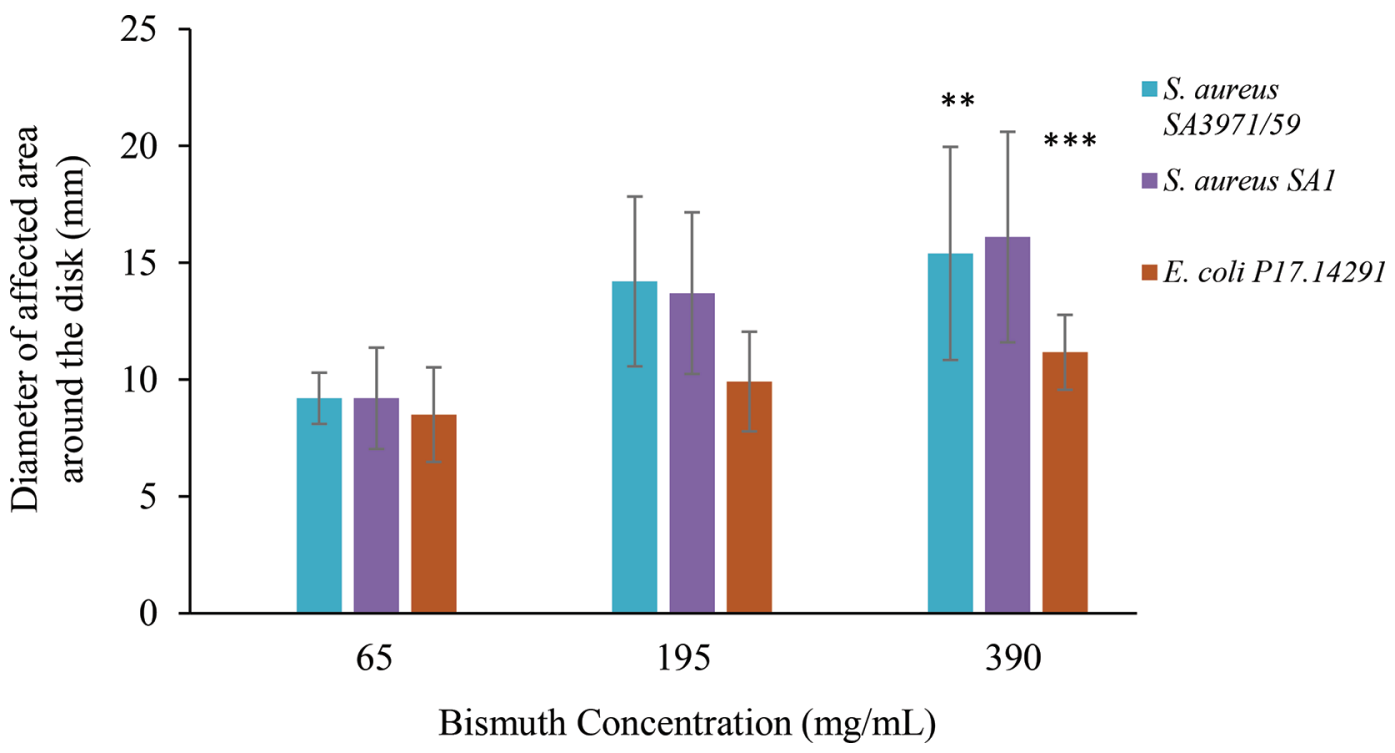

Figure 2. Experiment 1: Diameter of the area $( \pm \mathrm{SD})$ affected by bismuth subnitrate in the 6-mm disk diffusion test using Staphylococcus aureus SA3971/59, Staph. aureus SA1, and Escherichia coli P17.14291. Bars represent areas of dark coloration around the disk; n = 5. Dark areas around the disks varied with concentration within each Staph. aureus strain; ${ }^{* *} P<0.01,{ }^{* * *} P<0.001$.

from $3 \mathrm{~h}$ after the commencement of the culturing period (Figure 4). Trials 1 and 2 showed a very similar response to bismuth, with increased inhibition after $24 \mathrm{~h}$ for strains SR115, SA3971/59, and E. coli, but a resumption in growth of strain SA1 (Figure $4 \mathrm{C}$ ). The difference between BIS and CON flasks remained significant for most of the study in both trials.

\section{DISCUSSION}

Teat sealants containing bismuth subnitrate are described as inert nonantibiotic products that act as a physical barrier to the colonization of bacteria through the teat canal during the dry period (Meaney et al., 2001; Codex Alimentarius, 2016). However, our results support the concept that bismuth subnitrate slows bacterial growth in vitro. This is, to our knowledge, the first published assessment of a potential inhibitory effect of bismuth subnitrate on mastitis-causing agents in the dairy industry.

Streptococcus uberis is one of the main mastitis-causing microorganisms during the dry period, particularly in New Zealand (Williamson et al., 1995; McDougall, 2003). The results of the disk diffusion test in the present study (experiment 1) show that Strep. uberis SR115 appeared to be more susceptible to bismuth subnitrate than Staph. aureus (SA3971/59 and SA1) or E. coli (P17.1429), demonstrated by an area of complete inhibition. In the same test, Staph. aureus and E. coli presented an apparent concentration-dependent dark area around the disks, but not complete inhibition as for
Strep. uberis. The dark area observed for Staph. aureus and $E$. coli in this study could be explained by the fact that both strains have the ability to hydrolyze sulfide (Tomasova et al., 2016). The hydrolysis of sulfide with the addition of bismuth forms bismuth (3) sulfide, a black pigment produced by some bacteria in the mouth and lower intestines (Ioffreda et al., 2001). There are other examples in which bacteria in conjunction with bismuth can form bismuth 3 sulfide. The "black spot defect" found in cheddar cheese is produced by bismuth 3 sulfide and has been linked to the presence of bismuth subnitrate in the milk (Lay et al., 2007). The production of bismuth 3 sulfide, therefore, could have caused the dark area around the disk in the disk diffusion test of this study. However, the presence of sulfide in the TSA plates was not tested. The disk diffusion test in this study was used as a screening tool; other traditional methods for antimicrobial testing such as the use of Mueller Hinton plates that could be applied in dosedependent antimicrobial testing for bismuth subnitrate were not used.

Bismuth subnitrate is a heavy metal compound with low solubility that precipitates in fluid medium, thus it does not diffuse easily in agar. After observing the results of the disk diffusion test, 2 more experiments were designed to reassess the inhibitory effect of bismuth subnitrate that could have been masked by the minimum spread of the bismuth suspension observed on the surface of the agar plates in experiment 1. Due to marked precipitation of bismuth subnitrate observed in experiment 2, the third experiment was added. In 

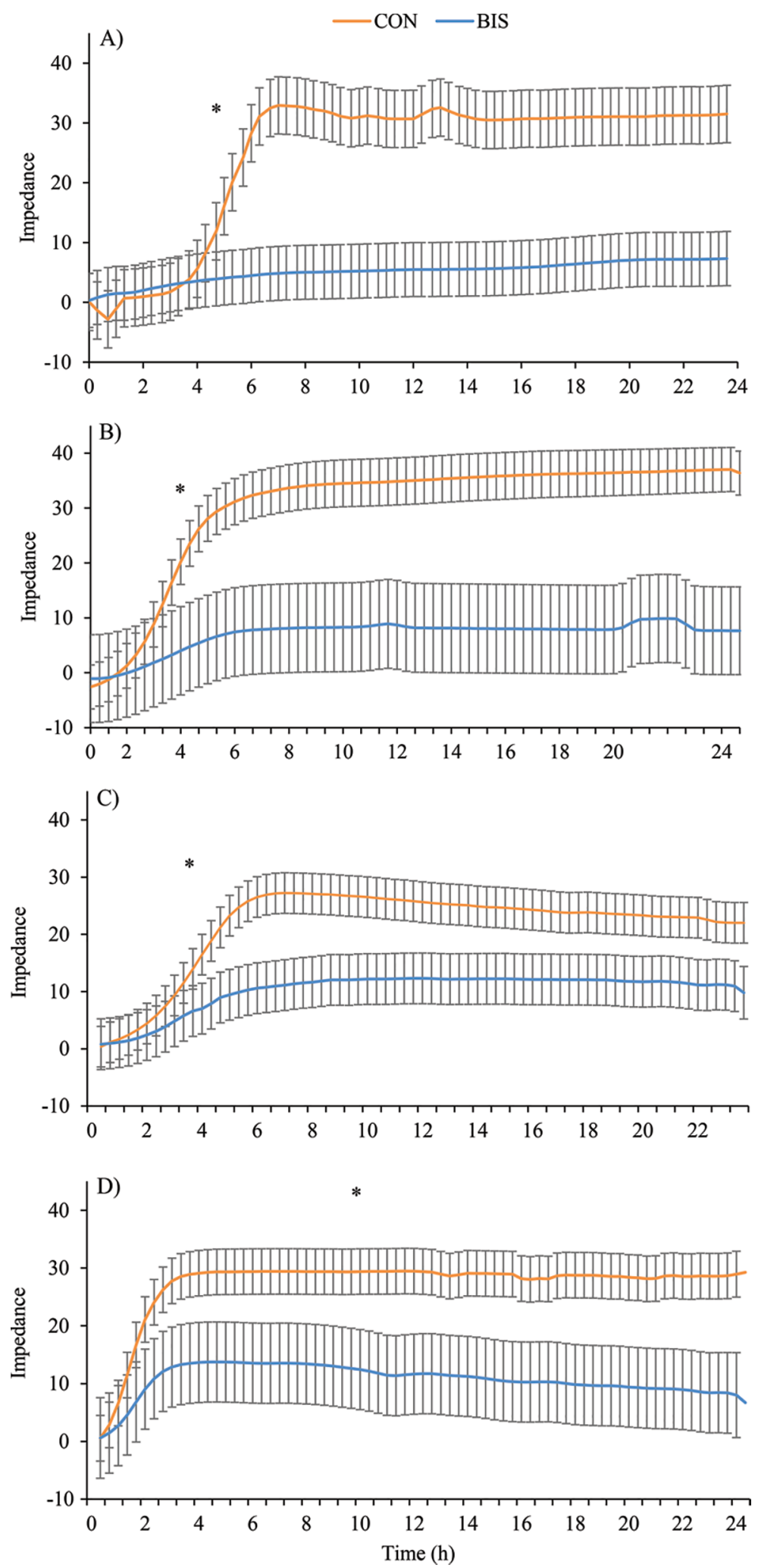

Figure 3. Experiment 2: Least squares means estimates of the impedance $( \pm 95 \%$ CI) measured in BacTrac 4300 (SyLab, Neupurkersdorf, Austria). Bacteria were cultured in trypticase soy broth with (BIS) and without bismuth (CON) for $24 \mathrm{~h}$ at $37^{\circ} \mathrm{C}$ in 4 repeats of triplicates per treatment. (A) Streptococcus uberis SR115 (BIS n =9, CON n = 8); (B) Staphylococcus aureus SA3971/59 $($ BIS n $=6$, CON n $=9) ;($ C) Staph. aureus SA1 (BIS n $=7$, CON n $=11$ ); (D) Escherichia coli P17.14291 (BIS n $=7$, CON n $=9$ ). $\mathrm{n}=$ number of vials that had readable results from BacTrac $4300 ; *$ first time point of difference $(P<0.05)$. 
Table 1. Experiment 2: Comparison of the mean $( \pm \mathrm{SD})$ of the $\log _{2}$ conversion of counts $(\mathrm{cfu} / \mathrm{mL})$ for bismuth subnitrate (BIS) versus control $(\mathrm{CON})$ vials before $(0 \mathrm{~h})$ and after $(24 \mathrm{~h})$ incubation at $37^{\circ} \mathrm{C}^{1}$

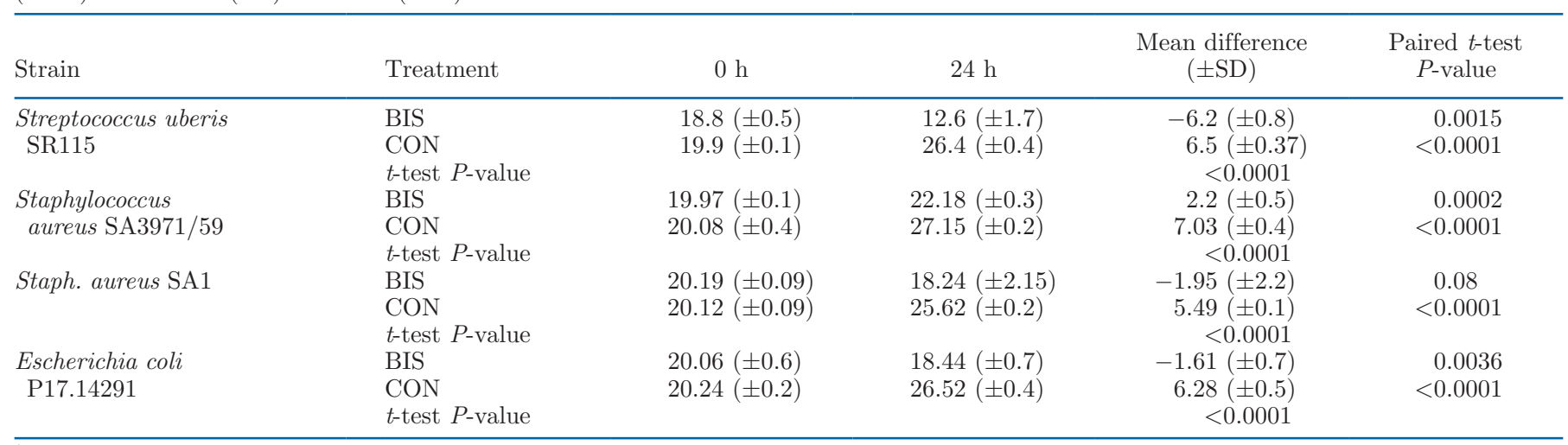

${ }^{1}$ Incubation in BacTrac 4300 (SyLab, Neupurkersdorf, Austria); $\mathrm{n}=6$ per strain.

the BacTrac and shaking medium studies (experiments 2 and 3 ), bacterial growth was significantly reduced by the presence of bismuth in the culture medium. There was no complete inhibition or killing, but the results clearly show a suppression of bacterial growth. Even though a low number of BacTrac vials could not be included in the analysis, due to a fault in some of the electrodes giving out-of-range readings, the results presented in this study show a significant difference in bacterial growth between BIS and CON vials. No explanation was found for the out-of-range readings. We hypothesized that bismuth precipitation over the base of the tube where the electrodes are placed had an effect, and this is one of the reasons that lead to the design of study 3 (shaking medium). However, literature reflects that it is not unusual to find outof-range measurements when measuring impedance (Colvin and Sherris, 1977). Ideal curve shapes that are meaningful for the purposes of the study need to be determined before the study (Chen and Chang, 1994), and we did this. Streptococcus uberis was the most susceptible strain to the effect of bismuth subnitrate in the 3 experiments presented here. In experiments 1 and 3, Strep. uberis showed complete inhibition after the 24-h culture with bismuth subnitrate. This could be due to its high sensitivity to bismuth subnitrate, or to inconsistent growth rates found in vitro in some Strep. uberis strains that are highly dependent on nutrient availability (Leigh and Field, 1991).

In experiment 3 , significant differences between BIS and CON flasks were observed after $3 \mathrm{~h}$ of culturing for all the strains. Experiment 2 produced significant differences after 4 to $5 \mathrm{~h}$ for most of the strains except for $E$. coli. For the latter, significant differences between BIS and CON vials were found $10 \mathrm{~h}$ after the culture began. The different nature of the studies and the dif- ferences in the statistical analyses performed for each of the experiments might have produced these time differences within the E. coli strain. Staphylococcus aureus SA1 resumed growth after $24 \mathrm{~h}$ in experiment 3 , but the origin of this resumption in growth could not be determined. The different growth rates of the 4 strains observed in this study support the concept of the presence of high variability in growth patterns and response to treatment of different pathogens (Keane, 2019). Staphylococcus aureus is usually associated with persistent IMI that may be present throughout the dry period (Pankey et al., 1982; Barkema et al., 2006). In contrast, E. coli and Strep. uberis tend to induce IMI or clinical mastitis cases that either cure spontaneously or for which the use of antimicrobials at dry off is usually effective (Todhunter et al., 1995; Keane, 2019). In this study, one of the Staph. aureus strains showed a resumption in growth after $48 \mathrm{~h}$ of exposure to bismuth subnitrate. This in vitro behavior may suggest adaptability of this strain to an adverse environment that could be relevant to the in vivo situation. This is why identification of the pathogen and a treatment that targets the bacterial agent (selective DCT) could improve cure rates during the dry period (Bradley and Green, 2001; Barkema et al., 2006). A limitation of this study is the absence of a positive control for the inhibitory effect. Experiments 2 and 3 would have benefited from having the impedance curve and counts obtained for vials with a known inhibitory agent.

Our results are in line with human medical and dentistry in vitro research studies showing the inhibitory effect of bismuth salts (mainly bismuth subsalicylate, but also bismuth subnitrate; Domenico et al., 1997; Athanikar, 1998; Lin et al., 2011; Vega-Jiménez et al., 2012). Bismuth-based products are used to treat different diseases, such as syphilis, gastric ulcers, traveler's 

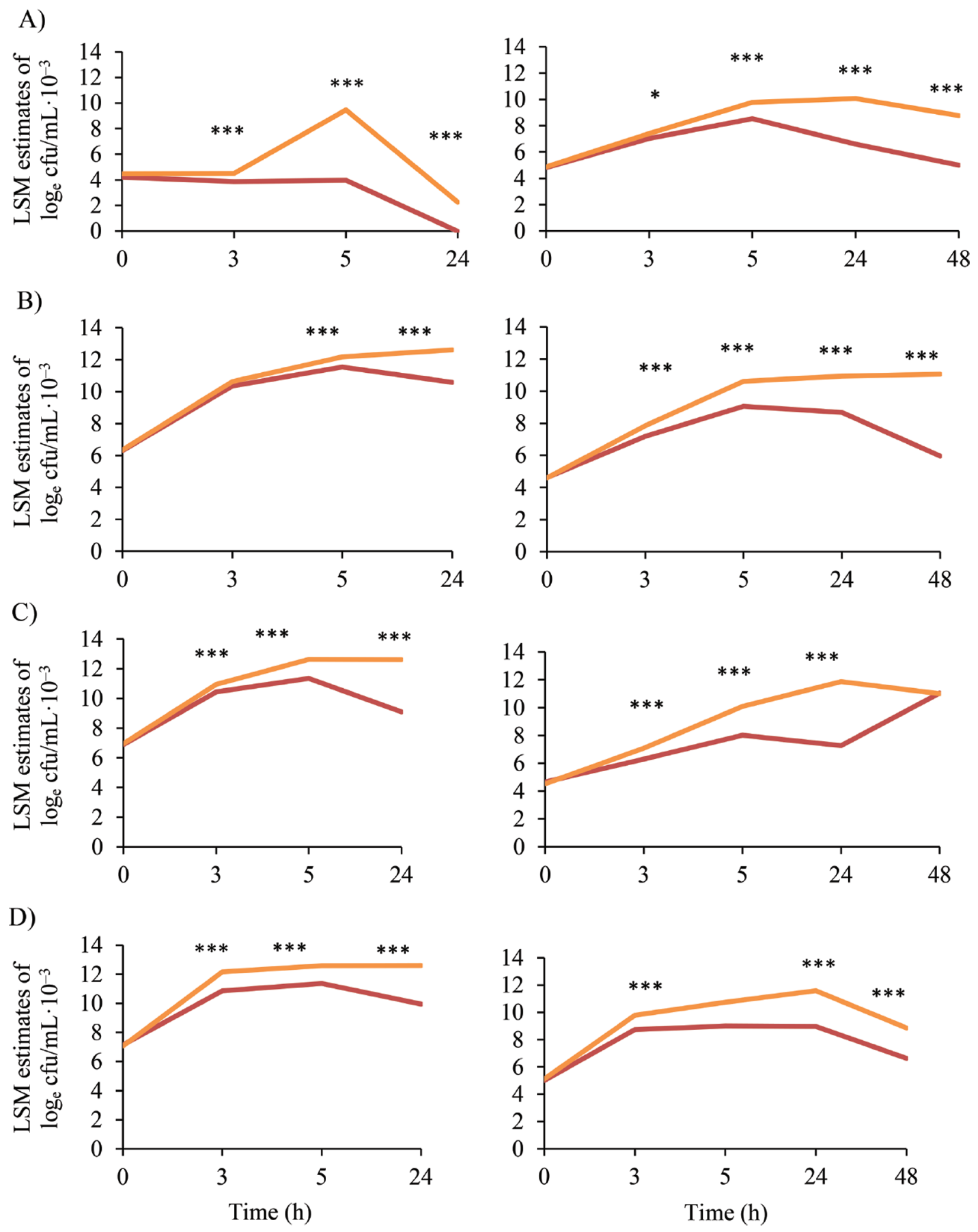

Figure 4. Least squares means estimates of e-log $(\mathrm{cfu} / \mathrm{mL}) / 10,000$ for trial 1 (left) and trial 2 (right) after culture at $37^{\circ} \mathrm{C}$ in shaking mode at $200 \mathrm{rpm}$ for 24 and $48 \mathrm{~h}$, respectively. (A) Streptococcus uberis SR115, (B) Staphylococcus aureus SA3971/59, (C) Staph. aureus SA1, and (D) Escherichia coli P17.14291. ${ }^{*} P<0.05 ;{ }^{* * *} P<0.0001$. Vials did (BIS) or did not (CON) contain bismuth subnitrate. 
diarrhea, and other pathologies caused mainly by bacteria (Marshall et al., 1987; Slikkerveer and de Wolff, 1989; Phillips et al., 2000).

The mechanism of action by which bismuth subnitrate slows bacterial growth is unknown. A few different hypotheses could explain this effect: oxidation, interference with bacterial metabolism by reducing ATP synthesis, enzyme inhibition, and inhibition of biofilm formation, among others (Sox and Olson, 1989; Zhang et al., 2006; Folsom et al., 2011). As an oxidizing heavy metal, the action mechanism of bismuth might be similar to that of other metals such as silver, zinc oxide $(\mathrm{ZnO})$ or copper, which are known for their antimicrobial and antifungal effects (Kim et al., 2007; Pasquet et al., 2014). For example, the antimicrobial effect of $\mathrm{ZnO}$ is due to the production of reactive oxygen species, the destabilization of microbial membranes when in contact with $\mathrm{ZnO}$ particles, and the antimicrobial properties of $\mathrm{Zn}^{2+}$ ions released by $\mathrm{ZnO}$ in an aqueous medium (Pasquet et al., 2014). Reduction of ATP synthesis in bacterial cells could be due to either a direct effect on bacterial metabolism or interference with the extracellular membrane function, inhibiting the transport of nutrients (Sox and Olson, 1989; Sadler et al., 1999). Bismuth has also been demonstrated to inhibit ureases, which are essential in some bacteria, and thus, it interferes with vital bacterial metabolism that culminates in bacterial death. However, Strep. uberis is a urease-negative bacterium and showed high susceptibility to bismuth in the present study, suggesting that the action mechanism of bismuth, in this case, could be different. Bismuth compounds were also found to be effective inhibiting and disrupting biofilm formation (Folsom et al., 2011; Hernandez-Delgadillo et al., 2012). The 4 strains used here were non-biofilm formers when cultured in TSB (Sarah Chia Jia Ning, School of Chemical Engineering and Food Technology, Singapore Institute of Technology; personal communication). Hence, this might not be the reason for the inhibition of growth observed in this study. It is not known whether biofilm inhibition by bismuth subnitrate teat sealants is an action mechanism that happens in vivo.

Our in vitro results are in part supported by the findings of several in vivo studies. In a study using nulliparous heifers, the application of bismuth subnitrate before parturition reduced the prevalence of IMI after calving compared with pretreatment infection levels, suggesting that bacterial growth might have slowed after being in contact with bismuth-based teat sealants (Parker et al., 2007). Another study also reported a lower prevalence of CNS infections post-calving in a group of cows treated with internal teat sealant (Berry and Hillerton, 2002). Bismuth subnitrate in the internal teat sealant could have inhibited the growth of bacteria in the teat canal to undetectable levels, which could assist in preventing bacterial invasion over the dry period. However, this requires experimental testing.

Other mechanisms in mastitis prevention of the bismuth-based teat sealants currently under investigation are the stimulation of the immune response, formation of a physical barrier, and prevention of biofilm formation, among others. Most studies comparing the efficacy of teat sealants with antibiotic DCT showed no difference in clinical mastitis incidence during the dry period and after calving (Woolford et al., 1998; Huxley et al., 2002). Interestingly, these studies state that the bismuth-based internal seal was as effective as an antibiotic in preventing new IMI over the dry period (Huxley et al., 2002; Bhutto et al., 2011; Rabiee and Lean, 2013). Our results showing inhibition of bacterial growth by bismuth subnitrate might at least partially explain these observations. The inhibitory effect of bismuth could be avoiding the colonization of the teat canal by mastitis pathogens during the dry period. However, in our studies, bismuth subnitrate was tested in a powder form and not within a teat sealant formulation with other excipients.

The results of this study provide impetus for the reconsideration of the definition of internal teat sealants as "inert." The word "inert" might not accurately reflect all mechanisms contributing to the efficacy of the bismuth subnitrate-based products. Further in vitro experiments are required before the observations reported herein can be applied in vivo. It would be important to assess the effect of bismuth subnitrate within the teat sealant formulations on bacterial growth at different concentrations and with different pathogens, for example, CNS and different streptococci. These organisms are highly prevalent throughout the dry period in dairy cows and heifers (Green et al., 2002; Parker et. al., 2008).

\section{CONCLUSIONS}

The results obtained in these in vitro studies show that bismuth subnitrate slowed bacterial growth in 4 major mastitis-causing agents to different degrees. This suggests that the efficacy of bismuth subnitrate-based teat sealants in preventing clinical mastitis may at least in part be due to a reduction in growth of the major mastitis-causing agents, particularly Strep. uberis, in the teat canal during the early stages of IMI in the dry period. In addition to the barrier effect described in previous works, the presence of an inhibitory effect in bismuth subnitrate formulations might be crucial for their high efficacy as documented. It may also indicate 
that new intramammary methods to prevent mastitis over the dry period will require inhibitory substances in addition to barrier components.

\section{ACKNOWLEDGMENTS}

This study was funded by Bayer New Zealand Ltd. (Bayer Animal Health, Auckland, New Zealand). We thank Ian Bruce (AgResearch, Animal Science, Infectious Diseases Team, Hopkirk Institute, Palmerston North, New Zealand), Scott McDougall (Cognosco - Anexa FVC, Morrinsville, New Zealand), and Alex Grinberg (School of Veterinary Science, Massey University, Palmerston North, New Zealand) for kindly providing the bacterial strains used in the study. Sarah Chia Jia Ning (School of Chemical Engineering and Food Technology, Singapore Institute of Technology) is gratefully acknowledged for her support in the laboratory. The authors have not stated any conflicts of interest.

\section{REFERENCES}

Athanikar, N. K. 1998. Chewing gum containing colloidal bismuth subcitrate. Josman Laboratories Inc., assignee. US Pat. No. 5,834,002.

Barkema, H. W., Y. H. Schukken, and R. N. Zadoks. 2006. The role of cow, pathogen, and treatment regimen in the therapeutic success of bovine Staphylococcus aureus mastitis. J. Dairy Sci. 89:18771895. https://doi.org/10.3168/jds.S0022-0302(06)72256-1.

Berry, E. A., and J. E. Hillerton. 2002. The effect of an intramammary teat seal on new intramammary infections. J. Dairy Sci. 85:25122520. https://doi.org/10.3168/jds.S0022-0302(02)74334-8.

Bhutto, A. L., R. D. Murray, and Z. Woldehiwet. 2011. The effect of dry cow therapy and internal teat-sealant on intra-mammary infections during subsequent lactation. Res. Vet. Sci. 90:316-320. https://doi.org/10.1016/j.rvsc.2010.06.006.

Bradley, A. J., and M. J. Green. 2001. An investigation of the impact of intramammary antibiotic dry cow therapy on clinical coliform mastitis. J. Dairy Sci. 84:1632-1639. https://doi.org/10.3168/jds .S0022-0302(01)74598-5.

Bryan, M. A., C. Heuer, and F. R. Emslie. 2011. The comparative efficacy of two long-acting dry-cow cephalonium products in curing and preventing intramammary infections. N. Z. Vet. J. 59:166-173. https://doi.org/10.1080/00480169.2011.579245.

Chen, H. C., and T. C. Chang. 1994. Detection of penicillin G in milk using a conductimetric method. J. Dairy Sci. 77:1515-1520. https: //doi.org/10.3168/jds.S0022-0302(94)77091-0.

Codex Alimentarius. 2016. Codex committee on residues of veterinary drugs in foods. Pages 1-6. Vol. RVDF/23 CRD/22. 21 October 2016 ed. http://www.fao.org/fao-who-codexalimentarius/ sh-proxy / en/?lnk=1\&url=https $\% 253 \mathrm{~A} \% 252 \mathrm{~F} \% 252 \mathrm{~F}$ workspace fao.org\% 252Fsites\%252Fcodex\% 252FMeetings\% 252FCX-730-23 \%252FCRD\%252Frv23_CRD22x_.pdf.

Colvin, H. J., and J. C. Sherris. 1977. Electrical impedance measurements in the reading and monitoring of broth dilution susceptibility tests. Antimicrob. Agents Chemother. 12:61-66. https://doi .org/10.1128/AAC.12.1.61.

Cousins, C. L., T. M. Higgs, E. R. Jackson, F. K. Neave, and F. H. Dodd. 1980. Susceptibility of the bovine udder to bacterial infection in the dry period. J. Dairy Res. 47:11-18. https://doi.org/10 $.1017 /$ S0022029900020823.

Domenico, P., R. J. Salo, S. G. Novick, P. E. Schoch, K. Van Horn, and B. A. Cunha. 1997. Enhancement of bismuth antibacterial activ- ity with lipophilic thiol chelators. Antimicrob. Agents Chemother. 41:1697-1703. https://doi.org/10.1128/AAC.41.8.1697.

Fine, K. D., and E. L. Lee. 1998. Efficacy of open-label bismuth subsalicylate for the treatment of microscopic colitis. Gastroenterology 114:29-36. https://doi.org/10.1016/S0016-5085(98)70629-8.

Folsom, J. P., B. Baker, and P. S. Stewart. 2011. In vitro efficacy of bismuth thiols against biofilms formed by bacteria isolated from human chronic wounds. J. Appl. Microbiol. 111:989-996. https:// doi.org/10.1111/j.1365-2672.2011.05110.x.

Godden, S., P. Rapnicki, S. Stewart, J. Fetrow, A. Johnson, R. Bey, and R. Farnsworth. 2003. Effectiveness of an internal teat seal in the prevention of new intramammary infections during the dry and early-lactation periods in dairy cows when used with a dry cow intramammary antibiotic. J. Dairy Sci. 86:3899-3911. https://doi .org/10.3168/jds.S0022-0302(03)73998-8.

Green, M. J., L. E. Green, G. F. Medley, Y. H. Schukken, and A. J. Bradley. 2002. Influence of dry period bacterial intramammary infection on clinical mastitis in dairy cows. J. Dairy Sci. 85:25892599. https://doi.org/10.3168/jds.S0022-0302(02)74343-9.

Hassan, Z., R. C. W. Daniel, D. O'Boyle, and A. J. Frost. 1999. Effects of dry cow intramammary therapy on quarter infections in the dry period. Vet. Rec. 145:635-639. https://doi.org/10.1136/vr .145 .22 .635 .

Hernandez-Delgadillo, R., D. Velasco-Arias, D. Diaz, K. Arevalo-Niño, M. Garza-Enriquez, M. A. De la Garza-Ramos, and C. CabralRomero. 2012. Zerovalent bismuth nanoparticles inhibit Streptococcus mutans growth and formation of biofilm. Int. J. Nanomedicine 7:2109-2113. https://doi.org/10.2147/IJN.S29854.

Hoernig, K. J., D. M. Donovan, P. Pithua, F. Williams III, and J. R. Middleton. 2016. Evaluation of a lysostaphin-fusion protein as a dry-cow therapy for Staphylococcus aureus mastitis in dairy cattle. J. Dairy Sci. 99:4638-4646. https://doi.org/10.3168/jds.2015 $-10783$.

Huxley, J. N., M. J. Green, L. E. Green, and A. J. Bradley. 2002. Evaluation of the efficacy of an internal teat sealer during the dry period. J. Dairy Sci. 85:551-561. https://doi.org/10.3168/jds .S0022-0302(02)74108-8.

Ioffreda, M. D., C. A. Gordon, D. R. Adams, S. J. Naides, and J. J. Miller. 2001. Black tongue. Arch. Dermatol. 137:968-969.

Kabera, F., S. Dufour, G. Keefe, and J.-P. Roy. 2018. An observational cohort study on persistency of internal teat sealant residues in milk after calving in dairy cows. J. Dairy Sci. 101:6399-6412. https:// doi.org/10.3168/jds.2017-13986.

Keane, O. M. 2019. Symposium review: Intramammary infectionsMajor pathogens and strain-associated complexity. J. Dairy Sci. 102:4713-4726. https://doi.org/10.3168/jds.2018-15326.

Kim, J. S., E. Kuk, K. N. Yu, J.-H. Kim, S. J. Park, H. J. Lee, S. H. Kim, Y. K. Park, Y. H. Park, C.-Y. Hwang, Y.-K. Kim, Y.-S. Lee, D. H. Jeong, and M.-H. Cho. 2007. Antimicrobial effects of silver nanoparticles. Nanomedicine (Lond.) 3:95-101. https://doi.org/10 .1016/j.nano.2006.12.001.

Lay, A. M., K. M. Kolpin, D. A. Sommer, and S. A. Rankin. 2007. Hot topic: Black spot defect in Cheddar cheese linked to intramammary teat sealant. J. Dairy Sci. 90:4938-4941. https://doi.org/10 $.3168 /$ jds.2007-0385.

Leigh, J. A., and T. R. Field. 1991. Killing of Streptococcus uberis by bovine neutrophils following growth in chemically defined media. Vet. Res. Commun. 15:1-6. https://doi.org/10.1007/BF00497784.

Lin, D.-J., M.-T. Tsai, T.-M. Shieh, H.-L. Huang, J.-T. Hsu, Y.-C. Ko, and L.-J. Fuh. 2013. In vitro antibacterial activity and cytocompatibility of bismuth doped micro-arc oxidized titanium. J. Biomater. Appl. 27:553-563. https://doi.org/10.1177/0885328211414942.

Marshall, B. J., J. A. Armstrong, G. J. Francis, N. T. Nokes, and S. H. Wee. 1987. Antibacterial action of bismuth in relation to Campylobacter pyloridis colonization and gastritis. Digestion 37:16-30. https://doi.org/10.1159/000199555.

McDougall, S. 2003. Intramammary treatment of clinical mastitis of dairy cows with a combination of lincomycin and neomycin, or penicillin and dihydrostreptomycin. N. Z. Vet. J. 51:111-116. https://doi.org/10.1080/00480169.2003.36349. 
Meaney, W. 1977. Effect of a dry period teat seal on bovine udder infection. Irish J. Agric. Res. 16:293-299.

Meaney, W., D. Twomey, J. Flynn, C. Hill, and R. Ross. 2001. The use of a bismuth-based teat seal and the bacteriocin lacticin 3147 to prevent dry period mastitis in dairy cows. Pages 24-32 in Proc. Proceedings of the British Mastitis Conference, Garstang, UK.

Nickerson, S. C., R. L. Boddie, W. E. Owens, and J. L. Watts. 1990. Effects of novel intramammary device models on incidence of mastitis after experimental challenge. J. Dairy Sci. 73:2774-2784. https://doi.org/10.3168/jds.S0022-0302(90)78963-1

Oldham, E. R., and M. J. Daley. 1991. Lysostaphin: Use of a recombinant bactericidal enzyme as a mastitis therapeutic. J. Dairy Sci. 74:4175-4182. https://doi.org/10.3168/jds.S0022-0302(91)78612 $-8$

Paape, M. J., W. D. Schultze, N. J. Corlett, and B. T. Weinland. 1988. Effect of abraded intramammary device on outcome in lactating cows after challenge exposure with Streptococcus uberis. Am. J. Vet. Res. 49:790-792.

Pankey, J. W., R. M. Barker, A. Twomey, and G. Duirs. 1982. Comparative efficacy of dry-cow treatment regimens against Staphylococcus aureus. N. Z. Vet. J. 30:13-15. https://doi.org/10.1080/ 00480169.1982 .34860

Parker, K. I., C. W. R. Compton, F.M. Anniss, C. Heuer, and S. McDougall. 2008. Quarter-level analysis of subclinical and clinical mastitis in primiparous heifers following the use of a teat sealant or an injectable antibiotic, or both, precalving. J. Dairy Sci. 91:169-181. https://doi.org/10.3168/jds.2007-0212.

Parker, K. I., C. Compton, F. M. Anniss, A. Weir, C. Heuer, and S. McDougall. 2007. Subclinical and clinical mastitis in heifers following the use of a teat sealant precalving. J. Dairy Sci. 90:207-218. https://doi.org/10.3168/jds.S0022-0302(07)72622-X.

Pasquet, J., Y. Chevalier, J. Pelletier, E. Couval, D. Bouvier, and M.-A. Bolzinger. 2014. The contribution of zinc ions to the antimicrobial activity of zinc oxide. Colloids Surf. Physicochem. Eng. Aspects 457:263-274. https://doi.org/10.1016/j.colsurfa.2014.05.057.

Pearson, J. K., and C. L. Wright. 1969. Dry cow therapy as a means of controlling bovine mastitis. Vet. Rec. 84:294-298. https://doi.org/ $10.1136 / v r .84 .12 .294$.

Phillips, R. H., M. W. Whitehead, S. Lacey, M. Champion, R. P. H. Thompson, and J. J. Powell. 2000. Solubility, absorption, and anti-Helicobacter pylori activity of bismuth subnitrate and colloidal bismuth subcitrate: In vitro data do not predict in vivo efficacy. Helicobacter 5:176-182. https://doi.org/10.1046/j.1523 $-5378.2000 .00028 . x$.

Poutrel, B., M. Paape, C. Lerondelle, and R. Grappin. 1983. Attempts at preventing experimental Staphylococcus aureus mastitis by immunization and intramammary insertion of a polyethylene device (Stérilait). Ann. Rech. Vet. 14:13-20.

Rabiee, A. R., and I. J. Lean. 2013. The effect of internal teat sealant products (Teatseal and Orbeseal) on intramammary infection, clinical mastitis, and somatic cell counts in lactating dairy cows: A meta-analysis. J. Dairy Sci. 96:6915-6931. https://doi.org/10 $.3168 / \mathrm{jds} .2013-6544$.

Ryan, M. P., W. J. Meaney, R. P. Ross, and C. Hill. 1998. Evaluation of lacticin 3147 and a teat seal containing this bacteriocin for inhibition of mastitis pathogens. Appl. Environ. Microbiol. 64:2287-2290. https://doi.org/10.1128/AEM.64.6.2287-2290.1998.

Sadler, P. J., H. Li, and H. Sun. 1999. Coordination chemistry of metals in medicine: Target sites for bismuth. Coord. Chem. Rev. 185186:689-709. https://doi.org/10.1016/S0010-8545(99)00018-1.

Schukken, Y. H., J. Vanvliet, D. Vandegeer, and F. J. Grommers. 1993. A randomized blind trial on dry cow antibiotic infusion in a low somatic cell count herd. J. Dairy Sci. 76:2925-2930. https:// doi.org/10.3168/jds.S0022-0302(93)77632-8.
Serna-Cock, L., and O. V. Pabón-Rodríguez. 2016. Development of a teat bio-sealant and evaluation of its technological and functional properties. Probiotics Antimicrob. Proteins 8:111-119. https://doi .org/10.1007/s12602-016-9210-5.

Silley, P., and S. Forsythe. 1996. Impedance microbiology-A rapid change for microbiologists. J. Appl. Bacteriol. 80:233-243. https:/ /doi.org/10.1111/j.1365-2672.1996.tb03215.x.

Slikkerveer, A., and F. A. de Wolff. 1989. Pharmacokinetics and toxicity of bismuth compounds. Med. Toxicol. Adverse Drug Exp. 4:303-323. https://doi.org/10.1007/BF03259915.

Sox, T. E., and C. A. Olson. 1989. Binding and killing of bacteria by bismuth subsalicylate. Antimicrob. Agents Chemother. 33:20752082. https://doi.org/10.1128/AAC.33.12.2075.

Todhunter, D.A ., K. L. Smith, and J. S. Hogan. 1995. Environmental streptococcal intramammary infections of the bovine mammary gland. J. Dairy Sci. 78:2366-2374. https://doi.org/10.3168/jds .S0022-0302(95) 76864-3.

Tomasova, L., P. Konopelski, and M. Ufnal. 2016. Gut bacteria and hydrogen sulfide: The new old players in circulatory system homeostasis. Molecules 21:1558. https://doi.org/10.3390/ molecules21111558

Vanhoudt, A., K. van Hees-Huijps, A. T. M. van Knegsel, O. C. Sampimon, J. C. M. Vernooij, M. Nielen, and T. van Werven. 2018. Effects of reduced intramammary antimicrobial use during the dry period on udder health in Dutch dairy herds. J. Dairy Sci. 101:3248-3260. https://doi.org/10.3168/jds.2017-13555.

Vega-Jiménez, A. L., E. Berea-Montes, and A. Almaguer-Flores. 2012 Susceptibility of E. coli, P. aeruginosa, S. aureus and S. epidermidis to different bismuth compounds. MRS Proc. 1487:Imrc12-s4bo026. https://doi.org/10.1557/opl.2012.1525.

Wang, H., J. Palmer, and S. Flint. 2016. A rapid method for the nonselective enumeration of Yersinia enterocolitica, a foodborne pathogen associated with pork. Meat Sci. 113:59-61. https://doi .org/10.1016/j.meatsci.2015.11.005.

Wilde, C. J., C. Addey, P. Li, and D. G. Fernig. 1997. Programmed cell death in bovine mammary tissue during lactation and involution. Exp. Physiol. 82:943-953. https://doi.org/10.1113/expphysiol .1997.sp004075.

Williamson, J. H., M. W. Woolford, and A. M. Day. 1995. The prophylactic effect of a dry-cow antibiotic against Streptococcus uberis. N. Z. Vet. J. 43:228-234. https://doi.org/10.1080/00480169.1995 .35898

Woolford, M. W., J. H. Williamson, A. M. Day, and P. J. Copeman. 1998. The prophylactic effect of a teat sealer on bovine mastitis during the dry period and the following lactation. N. Z. Vet. J. 46:12-19. https://doi.org/10.1080/00480169.1998.36044.

Zhang, L., S. B. Mulrooney, A. F. K. Leung, Y. Zeng, B. B. C. Ko, R. P. Hausinger, and H. Sun. 2006. Inhibition of urease by bismuth (III): Implications for the mechanism of action of bismuth drugs. Biometals 19:503-511. https://doi.org/10.1007/s10534-005-5449 -0 .

\section{ORCIDS}

S. Notcovich (1) https://orcid.org/0000-0003-3953-8476

N. B. Williamson () https://orcid.org/0000-0001-8286-2250

S. Flint (i) https://orcid.org/0000-0002-1027-6241

J. Yapura (1) https://orcid.org/0000-0003-1474-5030

Y. H. Schukken () https://orcid.org/0000-0002-8250-4194

C. Heuer @ https://orcid.org/0000-0003-0449-1540 